\title{
駆血と固定が筋萎縮に与える影響
}

\author{
一ラットを用いた実験的研究—
}

\section{Effects of Ischemia and Immobility on Muscle Atrophy in Rats}

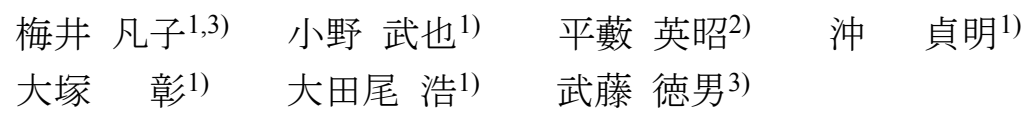

NAMIKo UMEI ${ }^{1,3)}$, TAKeYA ONO ${ }^{1)}$, Hideaki HIRAYABU ${ }^{2)}$, SADAAKI OKI ${ }^{1)}$, AKIRA OTSUKA $^{1)}$, HIROSHI OTAO ${ }^{1)}$, NORIO MUTO ${ }^{3)}$

1) Department of Physical Therapy, Faculty of Health and Welfare, Prefectural University of Hiroshima: 1-1 Gakuen Machi, Mihara City, Hiroshima 723-0053, Japan.TEL +81 848-60-1225 E-mail umei@pu-hiroshima.ac.jp

2) Kure Kyosai Hospital

3) Program in Biological System Sciences, Graduate School of Comprehensive Scientific Research, Prefectural University of Hiroshima

Rigakuryoho Kagaku 26(2): 259-262, 2010. Submitted Oct. 21, 2011. Accepted Dec. 2, 2010.

\begin{abstract}
Purpose] The purpose of this study was to determine the effects of ischemia and immobility on muscle atrophy in rats. [Subjects] Twenty-one eight-week-old Wistar female rats were randomly divided into three experimental groups: "immobile", "ischemic and immobile", and "ischemic". The left hind limb of the "immobile" group was used as the "control" group. [Methods] Ischemia and/or immobility were applied to the right hind limbs of the experimental groups. The relative weight ratios of the soleus muscles and the soleus muscle fiber cross-section minor axes were used for the evaluation of muscle atrophy. [Results] The soleus muscle relative weight ratios were highest in the "normal" group and decreased in order in the following groups "ischemia", "ischemia and immobile", "immobile". The soleus muscle fiber cross-section minor axes were highest in the "normal" group and decreased in order in the following groups "ischemia", "immobile", "ischemia and immobile". [Conclusion] Our results suggest that muscle atrophy caused by immobility and that caused by ischemia are independent entities.
\end{abstract}

Key words: ischemia, immobility, muscle atrophy

要旨：〔目的〕駆血と固定が筋萎縮に与える影響を検討すること。〔対象〕 8 週齢のWistar 系雌ラット 21 固体を無作 為に「固定群」,「駆血後固定群」,「駆血群」に振り分けた.「固定群」の対側肢を「正常群」とした.〔方法〕右大 腿にギプス固定や駆血の処置を行った．筋萎縮評価にはヒラメ筋相対体重比とヒラメ筋線維横断面短径を用いた。 〔結果〕多重比較検定の結果，ヒラメ筋相対体重比，ヒラメ筋線維横断面短径ともに「正常群」と比較すると「駆 血後固定群」「固定群」で有意に減少していた。 二元配置分散分析の結果, 駆血と固定での交互作用は認められな かった。〔結語〕固定により生じる廃用性筋萎縮と, 駆血により引き起こされる筋萎縮はそれぞれ独立して生じる ことが示唆された.

キーワード : ターニケット, 駆血, 廃用性筋萎縮

1) 県立広島大学 保健福祉学部理学療法学科：広島県三原市学園町1-1（テ723-0053）TEL 0848-60-1225

2) 吳共済病院

3) 県立広島大学大学院 総合学術研究科生命システム科学専攻

受付日 2010年10月21日受理日 2010年12月2日 


\section{I. はじめに}

四肢における整形外科的手術では，無血野の確保と 術中出血量の抑制を目的として，ターニケット（駆血 帯）が使用されることが多い1).しかし，ターニケット による駆血は，皮膚，骨格筋，神経，血管などに障害 を引き起こす可能性があると報告されている2). Appell ら ${ }^{3)}$ は, ラット後肢の駆血再灌流後に, 駆血部位より 末梢の細胞や代謝における変化と筋萎縮が生じていた と報告している。また，一般に臨床では整形外科術後， 術部への負担を軽減するため荷重制限やギプス固定に よる関節運動の制限など，不動を伴う一定期間の安静 を設ける。このような関節の不動や四肢の不使用（不 活動）は廃用性筋萎縮をもたらす4).これまでにラット を用いた動物実験においてターニケットによる駆血が 廃用性筋萎縮の進行過程に促進的な影響を及ぼすこと が示唆されている5).しかしその際，駆血と固定による 廃用が，それぞれどの程度，筋萎縮に影響しているの かは検討されていない.

そこで今回は，駆血と固定が筋萎縮に与える影響に ついて, それぞれどの程度であるかを検討するためラッ トを用いて実験を行った。

\section{II. 対象と方法}

1. 対象

対象は 8 週齢のWistar系雌ラット 21 個体である.これ らを無作為に 3 群に振り分けた。群分けは 15 日間のギ プス固定を行う「固定群」7肢，ターニケットによる駆 血後に 15 日間のギプス固定を行う「駆血後固定群」7 肢，駆血のみを行いギプス固定をせずに 15 日間自由飼 育する「駆血群」7肢である．なお，いずれのラットも 実験肢は右後肢とし, 「固定群」の左後肢を「正常群」 7 肢とした. すべてのラットは, 飼育ケージ内を自由に 移動でき, 水および慨の摂取も自由に行えるよう環境 を整えた。なお本研究は, 動物実験モデルであるため に県立広島大学の動物実験研究倫理委員会の承認 （No.19）を受けて実施した.

\section{2. 方法}

駆血には指用ターニケットカフ DC1.6, 加圧装置に はラピッドカフインフレータE20,カフインフレータエ アソースAG101（いずれもD.E.Hokanson社製，USA）を 使用した. 駆血圧は $250 \mathrm{mmHg}$ で駆血時間は60分間に設 定した。駆血は実験初日に「駆血群」,「駆血後固定群」 のラットに対し，ペントバルビタールナトリウム（40 $\mathrm{mg} / \mathrm{kg}$ ) 麻酔下にて右後肢大腿部にターニケットを装着 し行った.
また，「固定群」と駆血処置後の「駆血後固定群」の ラットの右後肢に対し, 15 日間のギプス固定を行った. 足関節を最大底屈位で保持し, 大腿から足趾にかけて 非伸縮性のテーピング（Johnson\&Johnson, TJ0600）を巻 き，その上からギプスにて固定し，さらにギプス保護 のため金網で覆った。ただし，足趾は浮腫の発生を確 認するため露出させた。固定期間中は毎日ギプスの緩 みや浮腫の観察を行い, 適宜ギプスの巻き替えを行った.

すべてのラットは実験開始時と実験終了時に体重計 測を行った. 体重計測後に腹部大動脈切断による脱血 にて屠殺後, 対象後肢のヒラメ筋を腓骨頭直下と踵骨 直上を切断し摘出した。摘出したヒラメ筋は, 直ちに 電子天秤で筋湿重量を測定した, さらにラットの個体 間の体重差を考慮するためラット体重 $(\mathrm{g})$ に対するヒ ラメ筋湿重量 $(\mathrm{mg})$ の比であるヒラメ筋相対体重比を 求めた.

ヒラメ筋湿重量測定後, ヒラメ筋は中央で2分割し, トラガカントゴムに包埋, 液体窒素で急速冷凍させ, 凍結したヒラメ筋組織の標本を作製した。凍結したヒ ラメ筋組織の標本はクリオスタットを使用し $10 \mu \mathrm{m}$ 厚 でヒラメ筋組織の横断切片を作製しへマトキシリン・ エオシン染色を施した。 ヒラメ筋組織の標本には筋線 維と間質結合組織が含まれている。そのため, 筀線維 のみの横断面の計測を行うため顕微鏡デジタルカメラ を用いて撮影した. 筋線維径は, 画像解析ソフト (Image ProPlus6.2J, USA）を用いて 200 本以上の筋線維短径の 計測を実施し，標本毎にヒラメ筋線維横断面短径の平 均值を求めた。筋線維径にヒラメ筋線維横断面の短径 を用いたのは切片を作製する際に筋組織長軸に対して 垂直に切れていない場合においても計測誤差が少ない からである，骨格筋の萎縮は筋組織に含まれる 1 本 1 本 の筋線維の萎縮で確認できるので, 正常群を $100 \%$ とし た場合の各群のヒラメ筋線維横断面短径の割合を計算 し, 得られた值を 100 から引くことで筋萎縮の割合を算 出した。

実験 2 日目から最終日までは, 駆血群ラットの歩行 観察を行った，その他の群については，右後肢をギプ ス固定しているため歩行観察の対象とはしなかった.

統計処理にはExcel 統計2007を用いた. 筋萎縮への影 響を分析するため, ヒラメ筋相対体重比とヒラメ筋線 維横断面短径を従属変数とし, 駆血の有無と固定の有 無を要因とした 2 元配置分散分析を行った. 2 元配置分 散分析の結果, 交互作用が認められず，各要因に主効 果を認めた場合に, 一元配置分散分析を行った。一元 配置分散分析はKruskal-Wallis 検定を適用し有意差を認 めた場合に下位検定として多重比較検定を行った。多 重比較検定にはScheffe の方法を適用した。なお，全て の統計手法は危険率5\%未満をもって有意差を判定した。 


\section{III. 結 果}

各群のヒラメ筋相対体重比およびヒラメ筋線維横断 面短径の平均值と標準偏差を表 1 に示す.

「正常群」のヒラメ筋相対体重比の平均值は $0.58 \mathrm{mg} /$ gであった。 それに対し「固定群」は $0.27 \mathrm{mg} / \mathrm{g}$,「駆血 後固定群」は $0.32 \mathrm{mg} / \mathrm{g}$, 「駆血群」は $0.55 \mathrm{mg} / \mathrm{g}$ であった. 多重比較検定の結果，「正常群」と比較すると「固定群」 と「駆血後固定群」は有意に減少していた。また，「駆 血群」に比較すると「固定群」は有意に減少していた (表1).

駆血の有無と固定の有無での二元配置分散分析の結 果，2要因間での交互作用は認められず，それぞれ独立 した要因であった（表 3）。また, 固定の有無において のみ主効果が認められた。

ヒラメ筋線維横断面短径の平均值は「正常群」で51.85 $\mu \mathrm{m}$ であった。 それに対し「固定群」は36.00 $\mu \mathrm{m}$,「駆血 後固定群」は30.67 $\mu \mathrm{m}$,「駆血群」は45.18 $\mu \mathrm{m}$ であった。 多重比較検定の結果は「正常群」と比較すると「固定 群」,「駆血後固定群」は有意に減少していた。また, 「駆血群」に比較すると「駆血後固定群」は有意に減少 していた（表1）。「正常群」のヒラメ筋線維横断面短径 を $100 \%$ として各群の筋萎縮の割合を計算した結果,「固 定群」30.6\%，「駆血後固定群」40.8\%，「駆血群」 12.9 \%であった（表2）.

駆血の有無と固定の有無での二元配置分散分析の結 果は，2要因間での交互作用は認められず，それぞれ独 立した要因であった（表3）。駆血の有無と固定の有無 の両方において主効果が認められた.

ヘマトキシリン・エオシン染色を施したヒラメ筋組 織の横断切片にてヒラメ筋形態学的検索を行った結果, 「正常群」では，ヒラメ筋線維横断面短径 $45 \sim 55 \mu \mathrm{m}$ を 中心とした筋細胞が密に配列している。「固定群」では ヒラメ筋線維横断面短径が「正常群」より短いものの 配列は密である。「駆血後固定群」と「駆血群」におい ては，骨格筋細胞間の間質結合組織に浮腫が見られ， 筋細胞は疎に配列している.

駆血群ラットの歩行観察を行った結果，駆血群の全 ラットにおいて, 駆血後 2 4 日間は跛行が観察された. 具体的には，歩行時の右後肢接地の消失，右後肢への 荷重不足であった。

\section{IV. 考 察}

前岡ら5) は, ラットヒラメ筋相対体重比について4 日 間から21日間のギプス固定により廃用性筋萎縮が認め られたものの, その進行過程における駆血の影響は認 められなかったと報告している.
表1 ヒラメ筋相対体重比およびヒラメ筋線維横断面短径の 結果 (平均值土標準偏差)

\begin{tabular}{lcc}
\hline 群分け & $\begin{array}{c}\text { ヒラメ筋相対体重比 } \\
(\mathrm{mg} / \mathrm{g})\end{array}$ & $\begin{array}{c}\text { ヒラメ筋線維横断面 } \\
\text { 短径 }(\mu \mathrm{m})\end{array}$ \\
\hline 正常群 & $0.58 \pm 0.02$ & $51.85 \pm 5.82$ \\
固定群 & $0.27 \pm 0.04^{\mathrm{ad}}$ & $36.00 \pm 1.68^{\mathrm{b}}$ \\
駆血後固定群 & $0.32 \pm 0.07^{\mathrm{b}}$ & $30.67 \pm 2.07^{\mathrm{ac}}$ \\
駆血群 & $0.55 \pm 0.09$ & $45.18 \pm 3.53$ \\
\hline
\end{tabular}

$\mathrm{a}$ : 「正常群」との有意差あり $\mathrm{p}<0.01$

$\mathrm{b}$ : 「正常群」との有意差あり $\mathrm{p}<0.05$

c : 「駆血群」との有意差あり $\mathrm{p}<0.01$

$\mathrm{d}$ : 「駆血群」との有意差あり $\mathrm{p}<0.05$

表2 ヒラメ筋線維横断面短径の結果と筋萎縮の割合（正 常群を $100 \%$ とした場合）

\begin{tabular}{lcc}
\hline 群分け & $\begin{array}{c}\text { ヒラメ筋線維横断面 } \\
\text { 短径 }(\mu \mathrm{m})\end{array}$ & $\begin{array}{c}\text { 筋萎縮の割合 } \\
(\%)\end{array}$ \\
\hline 正常群 & $51.85 \pm 5.82$ & 0.0 \\
固定群 & $36.00 \pm 1.68^{\mathrm{b}}$ & 30.6 \\
駆血後固定群 & $30.67 \pm 2.07^{\mathrm{a}}$ & 40.8 \\
駆血群 & $45.18 \pm 3.53$ & 12.9 \\
\hline
\end{tabular}

$\mathrm{a} ： 「$ 正常群」との有意差あり $\mathrm{p}<0.01$

$\mathrm{b}$ : 「正常群」との有意差あり $\mathrm{p}<0.05$

$\mathrm{c}$ : 「駆血群」との有意差あり $\mathrm{p}<0.01$

$\mathrm{d}$ ：「駆血群」との有意差あり $\mathrm{p}<0.05$

表3ヒラメ筋相対体重比とヒラメ筋線維横断面短径 における二元配置分散分析の結果

\begin{tabular}{ccc}
\hline 因子 & $\begin{array}{c}\text { ヒラメ筋相対 } \\
\text { 体重比 }\end{array}$ & $\begin{array}{c}\text { ヒラメ筋線維 } \\
\text { 横断面短径 }\end{array}$ \\
\hline 駆血 & 有意差なし & $*$ \\
固定 & $*$ & $*$ \\
駆血×固定 & 有意差なし & 有意差なし \\
\hline
\end{tabular}

*主効果あり $\mathrm{p}<0.01$

本研究では，ギプス固定を行った固定群と駆血後固 定群のヒラメ筋相対体重比は, ギプス固定を行わなかっ た正常群よりも有意に減少していた。さらに固定群に おいては駆血群に比較しても有意に減少していた。こ のことから，15日間のギプス固定による不動が，廃用 性筋萎縮を招いたと考えられる。また，正常群と駆血 群, 固定群と駆血後固定群間, 駆血群と駆血後固定群 には有意差は無く，ヒラメ筋相対体重比においては駆 血による影響が認められず，前岡ら5) と同様の傾向を 示した．駆血は浮腫を発生させるとの報告3,5-8)もある. 本研究におけるヒラメ筋形態学的検索の結果でも,「駆 血後固定群」と「駆血群」においては，骨格筋細胞間 の間質結合組織に浮腫が見られ，筋細胞は疎に配列し 
ていた。 そのため, 今回, ヒラメ筋相対体重比に有意 差が認められなかったのは浮腫の発生によりヒラメ筋 相対体重比が増加し，駆血による筋萎縮への影響を反 映しなかったのではないかと考えられる.

一方, ヒラメ筋線維横断面短径は正常群に比較しギ プス固定を行った固定群と駆血後固定群において有意 に減少していた。また，駆血群に比較して駆血後固定 群においても有意に減少していた。このことからヒラ メ筋相対体重比の結果と同様に固定によって廃用性筋 萎縮が生じたと考えられる.

Appell $ら^{7)}$ は, ヒトの外側広筋の筋生検を用いて駆血 と骨格筋への影響について実験を行ったところ, 病理 学的所見は駆血時間に応じて骨格筋構造の変化が生じ たと報告している。また，別の実験においてはラット ヒラメ筋を用い，60分間の駆血と60分間の再灌流によ り筋線維横断面積が減少したと報告している3 ${ }^{3)}$. 本研 究においては, 駆血群のヒラメ筋線維横断面短径は正 常群よりも減少しているものの有意差は認められなかっ た.このことから駆血再灌流により生じた筋萎縮は 15 日後には改善傾向を示していることが示唆された。

正常群と比較した場合の各群の筋萎縮の割合は，固 定群 : $30.6 \%$ ，駆血群 : $12.9 \%$ ，駆血後固定群 : $40.8 \%$ となった．駆血後固定群の筋萎縮の割合は固定群と駆 血群の筋萎縮の相加作用であると考えられる。このこ とからも，駆血による筋萎縮と固定による廃用性筋萎 縮は，それぞれ独立して生じることが示唆された。

本研究では, ターニケットによる駆血のみでも筋萎 縮が生じ，その影響はギプス固定により生じる廃用性 筋萎縮にプラスされることが示唆された。 術中駆血と ギプス固定を施された患者には，廃用性の筋萎縮に加 え駆血による筋萎縮が生じている可能性がある。つま り炎症と浮腫が生じていることを理解した上で治療を 行うことが必要である。

榊間ら 6) は，ラット下腿筋で 2 週間のギプス固定を 行ったところ, ギプス除去後 4 週間の通常飼育で正常 の $90 \%$ 程度に回復したと報告しており,適切な運動負荷 などの処置を行えば回復が促進される可能性があると 述べている. 他にも, 運動負荷が筋萎縮の予防や回復 の効果に大いに関係するということは多くの実験で述
ベられている ${ }^{9)}$ このように廃用性筋萎縮については 回復の可能性について検討されているものの, 駆血に よる筋萎縮の回復過程についての検討は少なく，その 詳細は不明である。今後, 駆血による筋萎縮の回復過 程, 運動療法の効果について検討していく必要がある.

本研究では, 8 週齢 Wistar 系ラットを実験対象とし, 後肢に対する 60 分間駆血と，15日間のギプス固定がそ れぞれどの程度筋萎縮に関与しているか検討した。そ の結果, 駆血のみを行った群に生じた筋萎縮の割合と, 固定のみを行った群に生じた筋萎縮の割合の和は，駆 血後に固定を行った群に生じた筋萎縮の割合と同程度 になった。この結果から，駆血により引き起こされる 筋萎縮と, 固定により生じる廃用性筋萎縮はそれぞれ 独立して生じることが示唆された。

\section{引用文献}

1) 田島正稔, 小保方浩一, 鍋島清隆・他: 人工膝関節全置換術 の駆血帯の有無による出血量の比較. 整形外科, 2003, 54(6): 711-713.

2) Kam PC, Kavanaugh R, Yoong FF:The arterial tourniquet: pathophysiological consequences and anaesthetic implications. Anaesthesia, 2001, 56: 534-545.

3) Appell HJ, Gloser S, Soares JMC, et al.: Structural alternations of skeletal muscle induced by ischemia and reperfusion. Basic Appl Myol, 1999, 9(5): 263-268.

4) 後藤勝正 : 廃用性筋萎縮を解明する 細胞骨格と不動による 変化. 総合リ八, 2002, 30(2): 119-125.

5) 前岡美帆, 小野武也, 梶原博毅・他 : ターニケットによる駆 血が廃用性筋萎縮に与える影響一ラットによる実験的研究 一. 理学療法学, 2009, 36 (5): 275-280.

6) 榊間春利, 甲斐 悟・小澤淳也・他 : ギプス固定によるラッ 卜下腿の萎縮と回復. 理学療法学, 2000, 27(5): 174-179.

7) Appell HJ, Gloser S, Duarte JAR, et al.: Skeletal muscle damage during tourniquet-induced Ischaemia. The initial step towards atrophy after orthopaedic surgery? Eur J Appl Physiol, 1993, 67(4): 342-347.

8) Knight KR, Messina A, Hurley JV, et al.: Muscle cells become necrotic rather than apoptotic during reperfusion of ischaemic skeletal muscle. Int J Exp Pathol, 1999, 80(3): 169-175.

9) 立野勝彦: 廃用性筋萎縮を解明寸る 下肢筋の組織学的変化 と臨床応用．総合リ八，2002, 30(2): 113-117. 